Jurnal Kejuruteraan SI 1(1) 2018: 25-30

http://dx.doi.org/10.17576/jkukm-2018-si1(1)-04

\title{
Effect of Temperature on the Mechanical Performance of Highly Conductive Composites for HT-PEMFC Application
}

\author{
(Kesan Suhu pada Prestasi Mekanikal Komposit Sangat Konduktif untuk Aplikasi HT-PEMFC) \\ Teuku Husainia,c,*, Shuhaimi ${ }^{\mathrm{a}}$, Abu Bakar Sulong ${ }^{\mathrm{a}, \mathrm{b}}$ \\ ${ }^{a}$ Fuel Cell Institute \\ ${ }^{b}$ Centre for Materials Engineering \& Smart Manufacturing (MERCU) \\ Universiti Kebangsaan Malaysia, Malaysia \\ ${ }^{c}$ Department of Chemical Engineering, \\ Universitas Sumatera Utara, Indonesia
}

\begin{abstract}
This study is a follow-up study of a previous study that examined the effect of temperature on the mechanical performance of the polymer carbon composite (CCP). In this study, the optimal formulation obtained from previous studies, was tried for use in polymer fuel cells of high temperature polymer electrolytes. The standard used is, the standard for bending strength specified by the US Department of Energy (DOE) Agency, which has determined the bending strength should be higher than 25 a. Preparation of CCP bipolar plates is done by internal mixing and then molded by compression stirring method. Bending strength and hardness test are carried out at $26^{\circ} \mathrm{C}$ to $200^{\circ} \mathrm{C}$, for $80 \%$ CNT/NG mixture and $20 \%$ by weight of EP, with a resin/hardener ratio of 3: 1. This composition has successfully met the bending strength standards set by the DOE on testing performed at room temperature. However, the composite electrical conductivity is still less than the standard set by DOE, reaching only $50 \mathrm{~S} / \mathrm{cm}$. The results show that the composite plate of CNT/NG/EP mixed with a 5/75/20\% by weight composition is not suitable for HT-PEMFC, because the filler and matrix composite interface failed to hold the bonds at temperature higher than the melting point of the EP. It is therefore recommended that this composite material be used only at low temperatures and is also not recommended for use as a fuel cell plate.
\end{abstract}

Keywords: Polymer composite; Bipolar plate; Fuel cell; Compression molding; Flexural strength; Hardness

ABSTRAK

Kajian ini merupakan kajian lanjutan dari kajian sebelumnya yang mengkaji kesan suhu terhadap prestasi mekanikal polimer karbon komposit (CCP). Pada kajian ini formulasi optimum yang telah didapatkan dari kajian terdahulu dicuba untuk digunakan untuk sel fuel membran elektrolit polimer bersuhu tinggi. Piawai yang digunakan adalah piawai untuk kekuatan lenturan yang telah ditetapkan oleh Agensi Jabatan Tenaga Amerika Syarikat (DOE), yang telah menetapkan kekuatan lenturan harus lebih tinggi daripada 25 MPa. Penyediaan plat dwikutub CCP dilakukan dengan pencampuran dalaman dan kemudian dicetak dengan kaedah pengacauan mampatan. Ujian kekuatan dan kekuatan lenturan dilakukan pada suhu $26^{\circ} \mathrm{C}$ hingga $200^{\circ} \mathrm{C}$ untuk campuran $80 \%$ berat MWCNTS/NG dan 20\% berat EP dengan nisbah resin/pengeras 3:1. Komposisi ini telah berjaya memenuhi piawai kekuatan lenturan yang ditetapkan oleh DOE pada pengujian yang dilakukan pada suhu bilik. Walau bagaimanapun, kekonduksian elektrik komposit masih kurang daripada piawai yang ditetapkan oleh DOE, hanya mencapai $50 \mathrm{~S} / \mathrm{cm}$. Keputusan menunjukkan bahawa plat dwikutub komposit MWCNTS/NG/EP yang dicampurkan dengan komposisi 5/75/20 wt\% tidak sesuai digunakan untuk HT-PEMFC, ini kerana antara muka komposit pengisi dan matriks gagal menahan ikatan pada suhu lebih tinggi daripada titik lebur EP. Oleh kerana itu disarankan bahan komposit ini untuk digunakan hanya pada suhu rendah sahaja dan ianya juga tidak disarankan untuk digunakan sebagai plat dwikutub sel fuel.

Kata kunci: Polimer komposit; Plat dwikutub; Sel fuel; Pengacuan mampatan; Kekuatan lenturan; Kekerasan

\section{INTRODUCTION}

Fuel cells work as energy conversion devices using electrochemical reactions of hydrogen and oxygen to generate electricity, as well as water as a by-product. The polymer electrolyte membrane fuel cell (PEMFC) is identified by the US Department of Energy (DOE) as the best candidate to replace the internal combustion engine in transportation applications (Tawfik et al. 2007).

The PEMFC is the most promising device for transportation applications because of its fast startup and immediate response to changes in the power demand, as well as its tolerance to shock and vibration because of its plastic materials and immobilized electrolyte (Shao et al. 2007). Energy generation 
occurs securely physicochemical, which can be produced DC electric continuously as long as the fuel is supplied. PEMFC also has other advantages such as small size, lightweight, high efficient and clean energy generator, it does not produce pollutants, such as $\mathrm{NO}_{\mathrm{x}}, \mathrm{SO}_{\mathrm{x}}$ and $\mathrm{CO}_{2}$ (Asri et al. 2017).

The PEMFC currently runs at a temperature of $\leq 80^{\circ} \mathrm{C}$ because of the PEM that has a working temperature limitation. Several challenges face PEMFCs that work at high temperatures $\left(\geq 80^{\circ} \mathrm{C}\right)$, especially in transportation applications such as heat rejection, tolerance $(<20 \mathrm{ppm})$, and impurity (CO and $\mathrm{H}_{2} \mathrm{~S}$ ) (Rosli et al. 2017).

Thus, many researchers have attempted to increase the PEMFC working temperature. The high temperature PEMFC (HT-PEMFC) operates at a temperature range of $100^{\circ} \mathrm{C}$ to $200^{\circ} \mathrm{C}$, because at high temperatures the operation of fuel cells has several advantages. The advantage of HT PEMFC is, the level of electrochemical kinetics is enhanced; water management and cooling are simplified; excess heat from which the reaction results can be used, etc. (Zhang et al. 2006).

Bipolar plates are the main components of the PEMFC stack (Asri et al. 2017). The portion of bipolar plate portion reaches $60 \%-80 \%$ of the total PEMFC stack component. This plate supplies fuel and oxidants to reaction area, removes by-products, as current collector, and provides mechanical support for the cells in the stack (Li \& Sabir 2005). Research on bipolar plates for HT-PEMFC application is still in its early stages and still requires more intensive research in terms of material properties used to fabricate the bipolar plate. The main objective of the present study is to determine whether a carbon nanotubes/graphite/epoxy (MWCNTs/G/EP) composite is suitable for use as a bipolar plate in HT-PEMFC application or not.

It is difficult for a single graphite $(\mathrm{G})$ graphite-composites composites material, to achieve the bipolar plate standard that has been targeted by the DOE (Suherman et al. 2013). The standard set by the US Department of Energy (DOE) for electrical conductivity is $100 \mathrm{~S} / \mathrm{cm}$ and the flexural strength should be greater than and $25 \mathrm{MPa}$ (Mohd Radzuan et al. 2018).

\section{METHODOLOGY}

This is the initial stage of the testing, to determine the strength and conductivity of the material. Subsequent testing, such as corrosion and porosity test will be carried out, if the first stage of testing reaches the standards set by the US-DOE, for bipolar plate standards to be used in the fuel cell application.

\section{EXPERIMENTAL}

This study was conducted to examine the possible abilities of bipolar plates studied in previous research (Suherman et al. 2013) for use in HT-PEMFC applications. Previous tests were conducted again by varying the temperature from room temperature, $26^{\circ} \mathrm{C}$, to $200^{\circ} \mathrm{C}$.
The use of two materials with high electrical conductivity of CNT and EP mixed in certain compositions is expected to improve the performance of material strengths on high conductivity (Sahari et al. 2016).

\section{MATERIALS}

The materials used to produce the CNTs/G/EP composite are a polymer matrix and filler. The CNTs used is multi-wall nanotubes (MWCNTS). MWCNTs can potentially increase the efficiency of electrical conductivity on polymer mixtures (Gojny et al. 2006). The thermoset polymer used in this experiment was EP Bisphenol-A (code 635) with a melting point of $150^{\circ} \mathrm{C}$ and sticky concentration of 6 poise (Suherman 2017). The curing agent was 4-aminophenylsulphone from the US composites. The G and CNTs properties used for the fillers are shown in Table 1.

TABLE 1. Properties of the synthetic graphite (SG) and MWCNTs fillers

\begin{tabular}{lcc}
\hline Filler & SG & MWCNTs \\
\hline Code & 3243 & NC 7000 \\
Density $\left(\left(\mathrm{g} / \mathrm{cm}^{3}\right)\right.$ & 1.7 & 1.34 \\
Thermal stability $\left({ }^{\circ} \mathrm{C}\right)$ & $350-400$ & 2800 \\
Average size & $\leq 44 \mu \mathrm{m}($ flake $)$ & $9.5 \mathrm{~mm}($ diameter $)$ \\
Resistance $(\Omega \mathrm{cm})$ & 0.036 & 0.0001 \\
Surface area $\left(\mathrm{m}^{2} / \mathrm{g}\right)$ & 3 & $250-300$ \\
Purity $(\%)$ & 99 & 93 \\
Supplier & Asbury Carbons & Nanocyl Belgium \\
& SDN BHD & \\
\hline
\end{tabular}

SG is selected as the filler because of its low resistance value, suitable thermal stability, flake shape, cheapness, and ease of mass production (i.e., it does not easily agglomerate) (Suherman et al. 2013). A CNTs is an allotrope of carbon with a cylindrical form and exhibits suitable electrical and thermal conductivities (Sulong et al. 2013). The composition of the MWCNTs/SG/EP in this experiment is fixed at 75/5/20 wt $\%$. This ratio is the best composition (Suherman et al. 2013) with a mechanical strength value particularly suitable for flexural strength and hardness within the DOE target (Table 2).

TABLE 2. US-DOE target for bipolar plate material properties

\begin{tabular}{lc}
\hline \multicolumn{1}{c}{ Property } & Value \\
\hline High electrical conductivity & $>100 \mathrm{~S} / \mathrm{cm}$ \\
High flexural strength & $>25 \mathrm{MPa}$ \\
High thermal conductivity & $>10 \mathrm{~W} / \mathrm{m} \mathrm{K}$ \\
High corrosion resistance & $<1 \mu \mathrm{A} / \mathrm{cm}^{2}$ \\
Low weight & $<0.4 \mathrm{~kg} / \mathrm{kW}$ \\
Low gas permeability & $<2 \times 10^{6} \mathrm{~cm}^{3} / \mathrm{s} \mathrm{cm}^{2 \circ} \mathrm{C}$ and $3 \mathrm{~atm}$ \\
\hline
\end{tabular}

POLYMER NANOCOMPOSITE FABRICATION

The preparation of the materials starts with the pre-mixing of the fillers (SG and MWCNTs) by using a ball milling machine for approximately $1 \mathrm{~h}$ at a speed of $200 \mathrm{rpm}$. Next, the EP 
is produced from a mixture of resin and hardener with a $3: 1$ ratio by using a mechanical mixer. Finally, the SG and MWCNTs pre-mixture is mixed with the EP in the internal mixer for approximately $30 \mathrm{~min}$. The homogeneous mixture of the composite is then poured into a square-shaped mold before being pressed at 1800 psi by using a hot compression machine.

The composite is then tested for its mechanical properties, such as flexural strength and hardness, at different temperatures (i.e., $100,125,150,175$, and $200^{\circ} \mathrm{C}$ ). Figure 1 shows the step involved in this experiment.

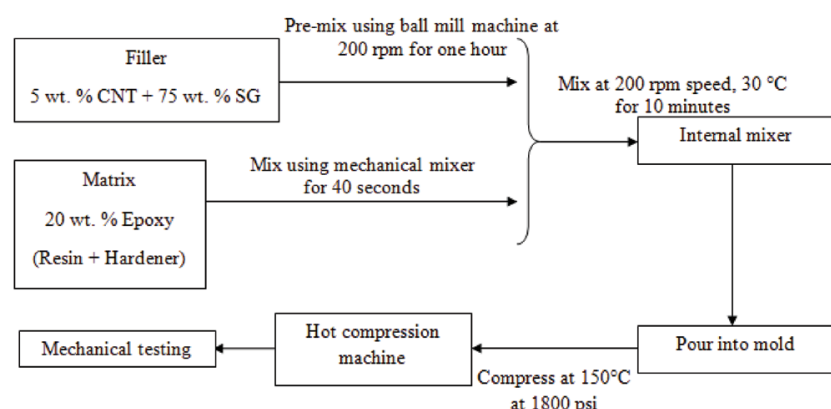

FIGURE 1. Process involved in fabricating the bipolar plate until the testing stage

\section{CHARACTERIZATION}

The mechanical properties of the composite plates in the flexural strength test were measured using a three-point bending test according to the ASTMD790-03 standard at different temperatures that range from room temperature to $200^{\circ} \mathrm{C}$. A universal testing machine Instron 5567 Model with a cross-head speed of $1 \mathrm{~mm} / \mathrm{min}$ was used in the said test (Liu et al. 2006).

The specimen dimensions were $100 \mathrm{~mm}^{3} \times 10 \mathrm{~mm}^{3}$ $\times 3.0 \mathrm{~mm}^{3}$, and the support span length was fixed at 50.0 $\mathrm{mm}$. The surface hardness test was conducted at different temperatures by using a heating plate covered with a Teflon and Shore-D hardness tester to record the reading. Fractured surfaces of the composite plates underwent scanning electron microscopy (SEM, Model Carl Zeiss Evo MA10) to observe the morphology of the conductive fillers in the polymer matrix and other microscopic features of the fracture surfaces.

\section{RESULTS AND DISCUSSIONS}

The first stage of testing is for physical / mechanical testing, the next testing phase will be carried out if the test results at this stage meet DOE standards.

\section{FLEXURAL STRENGTH OF THE MWCNTS/SG/EP COMPOSITE}

Figure 2 shows the variation in flexural strength of the MWCNTS/SG/EP composite as a function of temperature. Results show that the temperature effect on the composite is inversely proportional with the temperature applied to it. The highest flexural strength obtained at room temperature is $27.7 \mathrm{MPa}$, and the values continued to decrease until 2.8 $\mathrm{MPa}$ at a temperature of $200^{\circ} \mathrm{C}$.

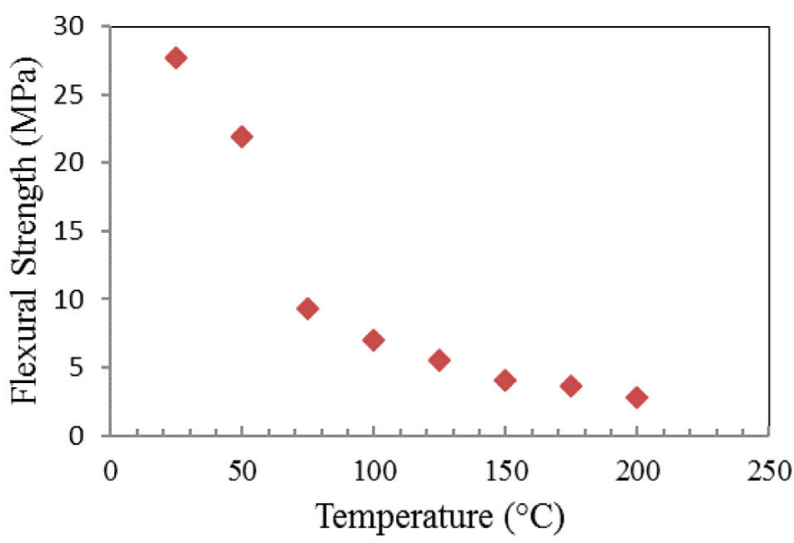

FIGURE 2. Temperature effect on flexural strength

A sudden drop occurred between the temperatures of 50 and $75^{\circ} \mathrm{C}$. At this point, the composite bonding started to fail, as shown in the SEM image in Figure 3. This condition is caused by the failure of the chemical bond between the filler and resin matrix, which occurs because of the crosslinking decomposition at high temperatures (Ghosh 2013).

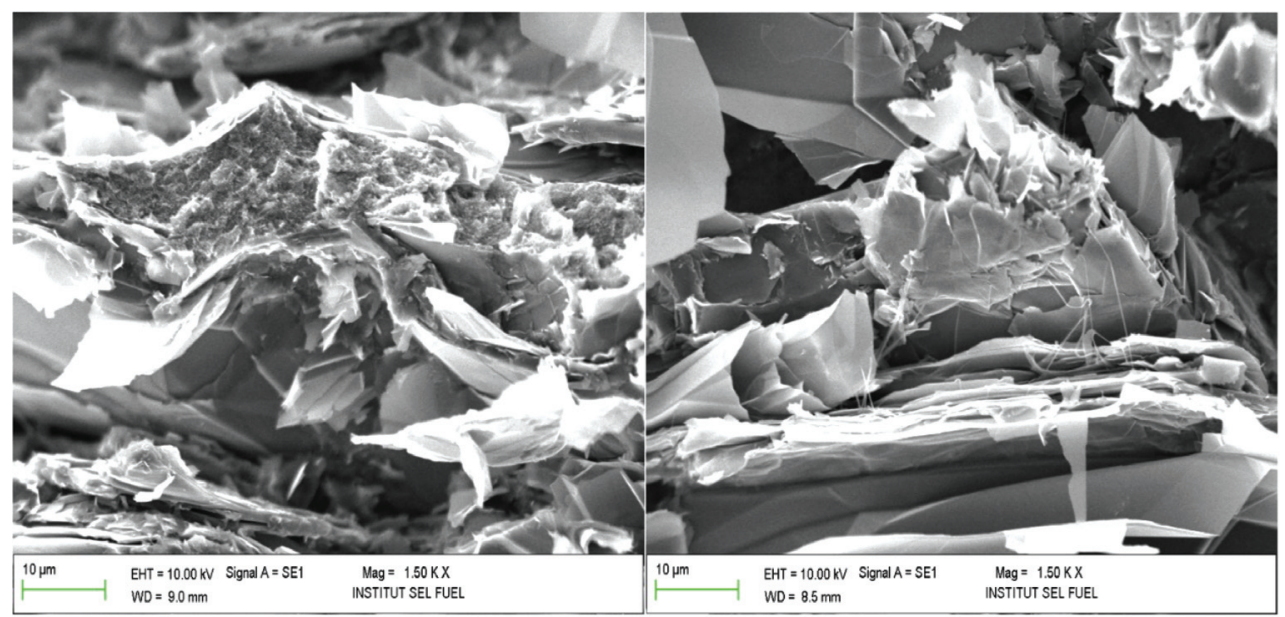

FIGURE 3. Crosslinking decomposition of the MWCNTS/SG/EP composite at high temperatures. SEM fracture surface at (a) 50 and (b) $75^{\circ} \mathrm{C}$ 
HARDNESS TEST ANALYSIS

Figure 4 shows the linear decrease in the composite hardness as the temperature increased. The highest hardness of the composite at 67.1 is obtained at room temperature, whereas the lowest hardness at 27.4 is obtained at $200^{\circ} \mathrm{C}$. The graph shows that a sudden drop occurred at a temperature between 175 and $200^{\circ} \mathrm{C}$. This condition can be attributed to the composite failing to resist the dislocation of indentation load because of the thermal decomposition of the cross-linkage between fillers and resin matrix. The SEM image in Figure 5 shows this scenario, which is also corroborated by the results of previous studies (Suherman et al. 2013).

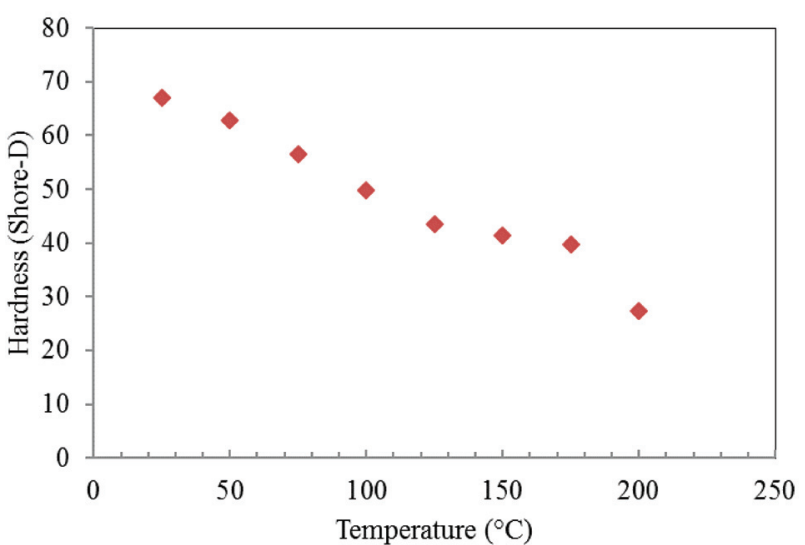

FIGURE 4. Temperature effect on hardness

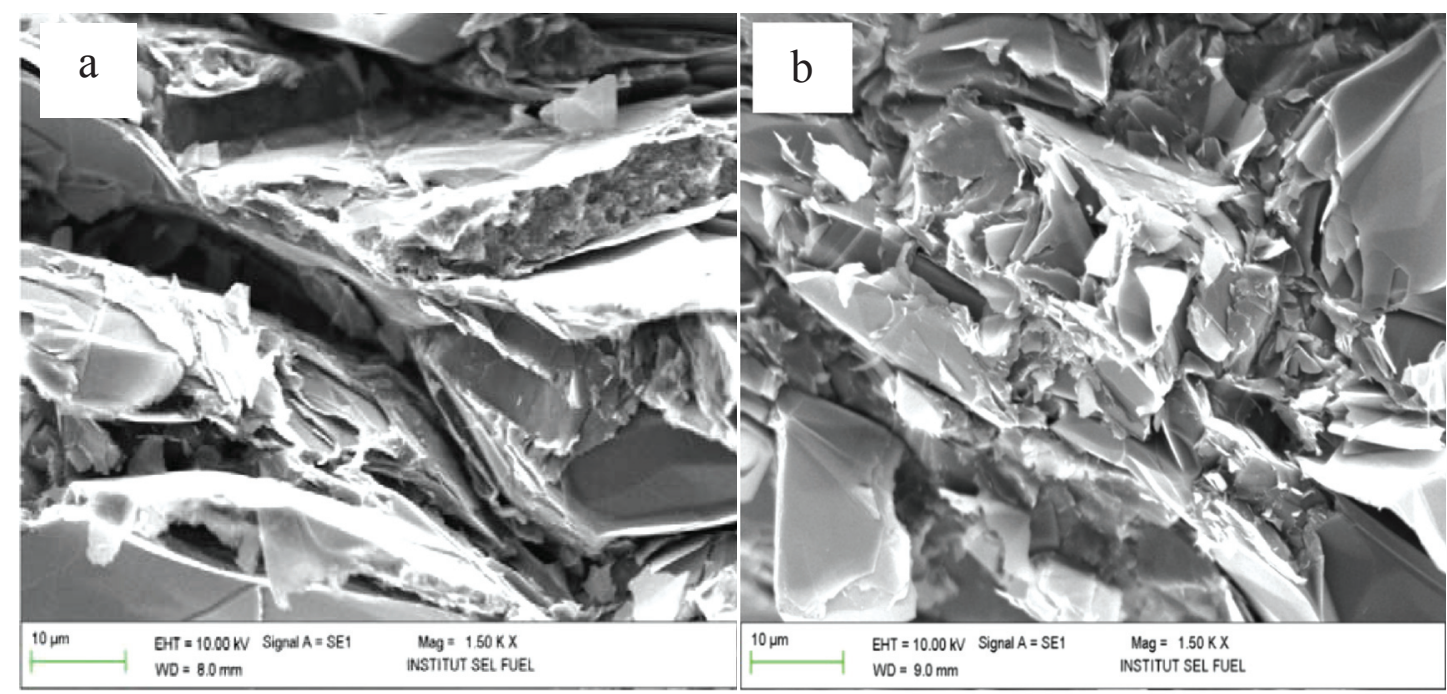

FIGURE 5. SEM fracture surface image of the CNT/SG/EP composites: (a) 175 and (b) $200^{\circ} \mathrm{C}$

Thermal Gravimetric Analysis (TGA) test results for pure EP material from previous studies (Suherman et al. 2013) are shown in Figure 6 . The analysis shows that a $4 \%$ reduction occurred at $300^{\circ} \mathrm{C}$. PEMFC operates at different temperatures, for low operating temperatures is below $100^{\circ} \mathrm{C}$ and high operating temperatures are 130 to $200^{\circ} \mathrm{C}$ (Radhakrishnan et al. 2007; T. Derieth 2009).

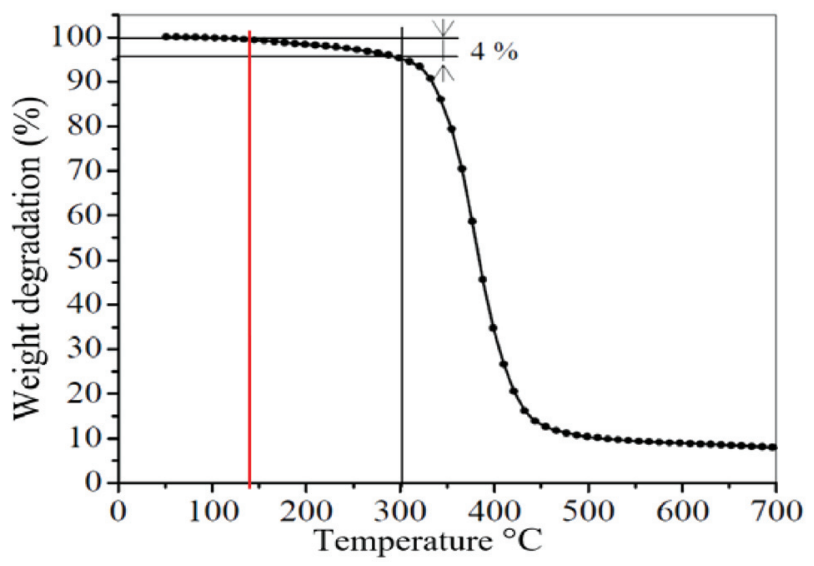

FIGURE 6. TGA test results for pure EP
In this study there was no weight loss for raw EP materials, if PEMFC was operating at low temperatures. TGA analysis of raw EP materials found that EP is stable at temperatures up to $150^{\circ} \mathrm{C}$ and showed only $4 \%$ reduction in weight at a temperature of $200^{\circ} \mathrm{C}$. Under these circumstances, the EP material is suitable for use as a raw material for conductive polymer composites manufacturing bipolar plates for lowtemperature PEMFCs. Decreasing the material strength at high temperatures is significant in the EP mixture with MWCNTs and graphite (Figure 7) (Suherman et al. 2013).

\section{CONDUCTIVITY}

Through-plane conductivity measurements are performed for temperatures that range from $25^{\circ} \mathrm{C}$ (room temperature) to $200^{\circ} \mathrm{C}$. Conductivity reading is conducted directly (real time) at different temperatures.

Figure 8 shows a significant increase in the conductivity until $175^{\circ} \mathrm{C}$. The conductivity devaluation started at temperatures above $175^{\circ} \mathrm{C}$ when the material started to become damaged. Material damage at $175^{\circ} \mathrm{C}$ can be seen physically, which indicates the start of the material deformation. 


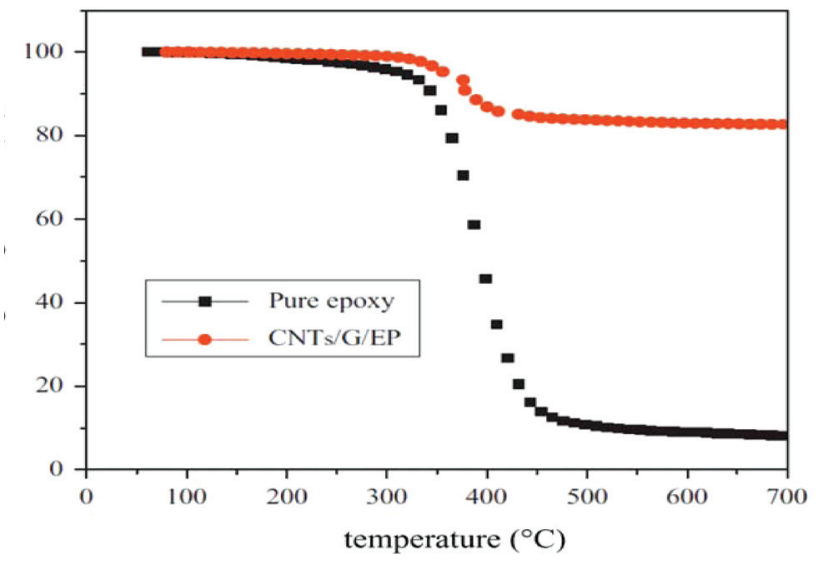

FIGURE 7. Optimum concentration of the polymer nanocomposite shown by the TGA curve

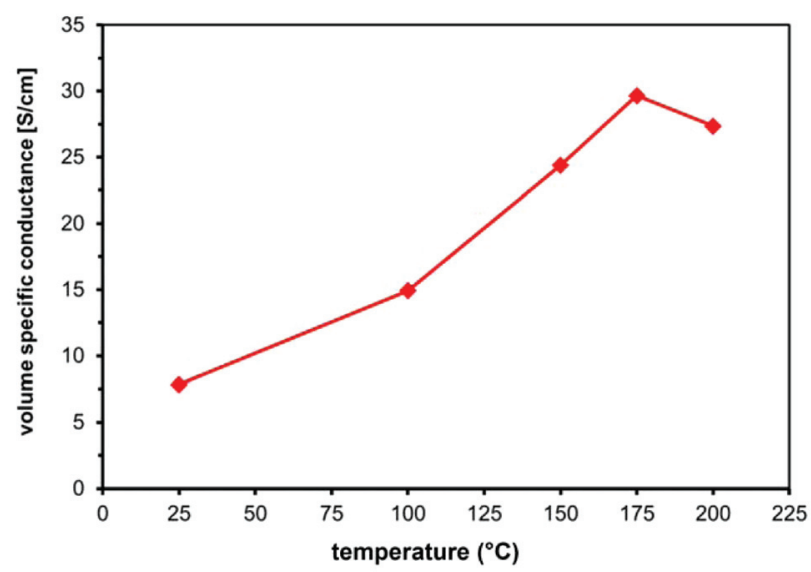

FIGURE 8. Temperature effect on the through-plane electrical conductivity of the MWCNTs/SG/EP composite

CONCLUSION

The flexural strength and shore hardness of the MWCNTs/ SG/EP composite are evaluated by applying a temperature function. Several conclusions are drawn based on the obtained results.

The results of the hardness testing show that the mixture can still survive when the temperature is $200^{\circ} \mathrm{C}$. The material strength value reached 67.1 (hardness shore-D). Nevertheless, this condition is similar to a decreasing impression hardness as the temperature increases.

The flexural test for the MWCNTs/SG/EP composite bipolar plate with a 5/75/20 wt. \% composition show that the material strength had a sudden drop when the temperature was more than $50^{\circ} \mathrm{C}$. A flexural value of $2.8 \mathrm{MPa}$ was obtained at a temperature of $200^{\circ} \mathrm{C}$ at the end of the test.

The analysis results show that the use of the MWCNTs/ SG/EP composite with a 75/5/20 wt. \% composition is the best option for low temperatures (Suherman et al. 2013), but is unsuitable for high temperatures.

\section{ACKNOWLEDGEMENT}

The authors gratefully acknowledge the financial support off or this work by the Universiti Kebangsaan Malaysia under the Grant Number FRGS/1/2017/TKK10/UKM/02/6 and GUP-2016-084.

\section{REFERENCES}

Asri, N. F., Husaini, T., Sulong, A. B., Majlan, E. H. \& Daud, W. R. W. 2017. Coating of stainless steel and titanium bipolar plates for anticorrosion in PEMFC: A review. International Journal of Hydrogen Energy 42(14): 9135-9148.

Derieth, T., Beckhaus, G. B., Kreuz, C. P., Mahlendorf, F. \& Heinzel, A. 2009. Development of highly filled graphite compounds as bipolar plate materials for low and high temperature PEM fuel cells. Journal of New Materials for Electrochemical Systems 11(1): 21-29.

Ghosh, A. 2013. Carbon-polymer composite bipolar plate for HT-PEMFC. Fuel Cells 14: 259-265.

Gojny, F. H., Wichmann, M. H. G., Fiedler, B., Kinloch, I. A., Bauhofer, W., Windle A. H. \& Schulte, K. 2006. Evaluation and identification of electrical and thermal conduction mechanisms in carbon nanotube/epoxy composites. Polymer 47(6): 2036-2045.

Li, X. \& Sabir, I. 2005. Review of bipolar plates in PEM fuel cells: Flow-field designs. International Journal of Hydrogen Energy 30(4): 359-371.

Liu, H.-Y., Yan, W. \& Mai, Y.-W. 2006. Z-pin bridging in composite laminates and some related problems. Australian Journal of Mechanical Engineering 3(1): 11-19.

Mohd Radzuan, N. A., Sulong, A. B., Rao Somalu, M., Majlan, E. H., Husaini, T. \& Rosli, M. I. 2018. Effects of die configuration on the electrical conductivity of polypropylene reinforced milled carbon fibers: An application on a bipolar plate. Polymers 10(5): 558.

Radhakrishnan, S., Ramanujam, B., Adhikari, A. \& Sivaram, S. 2007. High-temperature, polymer-graphite hybrid composites for bipolar plates: effect of processing conditions on electrical properties. Journal of Power Sources 163(2): 702-707.

Rosli, R., Sulong, A.B., Daud, W., Zulkifley, M., Husaini, T., Rosli, M., Majlan, E. \& Haque, M. 2017. A review of high-temperature proton exchange membrane fuel cell (HT-PEMFC) system. International Journal of Hydrogen Energy 42(14): 9293-9314.

Sahari, J., Sulong, A. B. \& Husaini, T. 2016. Beban serbuk kritikal dan sifat reologi bahan suapan komposit polipropilena/grafit untuk aplikasi plat dwikutub. Malaysian Journal of Analytical Sciences 20(3): 687696.

Shao, Y., Yin, G., Wang, Z. \& Gao, Y. 2007. Proton exchange membrane fuel cell from low temperature to high temperature: Material challenges. Journal of Power Sources 167(2): 235-242. 
Suherman, H. 2017. Optimization of internal mixing parameter on the electrical conductivity of multiwall carbon nanotubes/ synthetic graphite/ epoxy nanocomposites for conductive polymer composites using taguchi method. Jurnal Kejuruteraan 29(2): 79-85.

Suherman, H., Sahari, J. \& Sulong, A. B. 2013. Effect of small-sized conductive filler on the properties of an epoxy composite for a bipolar plate in a PEMFC. Ceramics International 39(6): 7159-7166.

Suherman, H., Sulong, A. B. \& Sahari, J. 2013. Effect of the compression molding parameters on the in-plane and through-plane conductivity of carbon nanotubes/ graphite/epoxy nanocomposites as bipolar plate material for a polymer electrolyte membrane fuel cell. Ceramics International 39(2): 1277-1284.

Sulong, A. B., Ramli, M. I., Hau, S. L., Sahari, J., Muhamad, N. \& Suherman, H. 2013. Rheological and mechanical properties of carbon nanotube/Graphite/SS316L/polypropylene nanocomposite for a conductive polymer composite. Composites Part B: Engineering 50: 5461.
Tawfik, H., Hung, Y. \& Mahajan, D. 2007. Metal bipolar plates for PEM fuel cell - A review. Journal of Power Sources 163(2): 755-767.

Zhang, J., Xie, Z., Zhang, J., Tang, Y., Song, C., Navessin, T., Shi, Z., Song, Wang, H. Wilkkinson, D. P., Liu, Z.-S. \& Holdcroft, S. 2006. High temperature PEM fuel cells. Journal of Power Sources 160: 872-891.

\section{*Teuku Husaini}

Fuel Cell Institute UKM,

Universiti Kebangsaan Malaysia, Bangi 43600, Malaysia.

*Corresponding author;

email: t.husaini.st@gmail.com

Received date: $7^{\text {th }}$ August 2018

Accepted date: $13^{\text {th }}$ September 2018

Online First date: $1^{\text {st }}$ October 2018

Published date: $30^{\text {th }}$ November 2018 